\title{
ASSESSMENT ON MARKING SPECIFICATION OF REAR SIDE OF HEAVY GOODS VEHICLES IN MALAYSIA
}

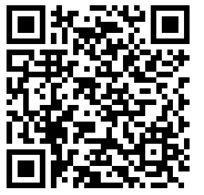

\author{
Siti Aishah Yahya ${ }^{1}$, Nor Azam Ramli ${ }^{1}$, Syabiha Shith ${ }^{*}{ }^{\star 凶}$, Nur Baitul Izati Rasli ${ }^{1}$ \\ ${ }^{*}$ Environmental Assessment and Clean Air Research, School of Civil Engineering, Engineering \\ Campus, Universiti Sains Malaysia, 14300, Nibong Tebal, Penang, Malaysia
}

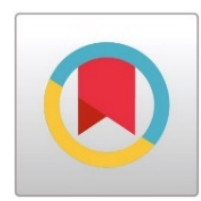

DOI: https://doi.org/10.29121/granthaalayah.v8.i9.2020.1572

Article Type: Research Article

Article Citation: Siti Aishah Yahya, Nor Azam Ramli, Syabiha Shith, and Nur Baitul Izati Rasli. (2020).

ASSESSMENT ON MARKING

SPECIFICATION OF REAR SIDE OF

HEAVY GOODS VEHICLES IN

MALAYSIA. International Journal of

Research -GRANTHAALAYAH, 8(9), 283-295.

https://doi.org/10.29121/granthaa

layah.v8.i9.2020.1572

Received Date: 14 September 2020

Accepted Date: 30 September 2020

Keywords:

Conspicuity

Lorries

Rear Accidents

Rear Marking

Visibility

\begin{abstract}
A vehicle's conspicuity is determined by the colour and pattern of painted surfaces, height, lighting system, reflectorization and fluorescent markings. In Malaysia, the better visibility of heavy goods vehicles has to be marked with retroreflective marking. The objectives of the study to analyse percentages of marking requirement that compliant with the MS 828:2011. The study was conducted at Jawi Toll Plaza, Nibong Tebal, Pulau Pinang from 9.00 a.m. to 5.00 p.m for three days. As a result, the highest compliance level of marking requirement was $96 \%$ which is box truck two axles. Meanwhile, other categories were between $17 \%$ to $91 \%$. Many HGVs were not installing rear-end marking type 5, while all trucks and trailers with a maximum gross vehicle weight (GVW) of $3500 \mathrm{~kg}$ and above had to be marked with Type 5 (contour marking) as of 1 July 2019. Some improvement needed to reduce the severity and the number of road accidents by recommended a safe following distance.
\end{abstract}

\section{INTRODUCTION}

Conspicuity issues may contribute to the rear end and underride truck accidents. Rear-end truck crash happens when heavy trucks are driving at a slower speed than other vehicles. This high-speed differential between heavy vehicles and other vehicles will lead to possible collisions on the rear end [1]. Conspicuity plays a significant role, mainly involved in the accident at night. Bad visible of the night's rigid or articulated truck where drivers failed to see the truck turning off on the road, turning and driving ahead [2]. The truck can be more visible by labelling retroreflective labels on the sides and rear of commercial vehicles.

Malaysia has been listed as the third-highest number of death in road accident since in 2011 among the other countries [3]. The state of Selangor has the highest rate of accidents and keep increasing from 100380 in 2008 to 154958 in 2017. The total motor vehicle involved in road accidents by trucks or lorry risen from 48250 in 2008 to 530438 in 2011. It decreased to 34942 in 2015 due to the safety measures taken by the government [4].

(C) 2020 The Author(s). This is an open access article distributed under the terms of the Creative Commons Attribution License, which permits unrestricted use, distribution, and reproduction in any medium, provided the original author and source are credited. 
Brightness and conspicuity are two factors influencing the visibility of a heavily stationary vehicle. The luminance of a truck parked on the shoulder at night is based on the lights of the truck and the retro-reflective tape. Conspicuity is dependent on the colour and brightness of the natural environment [5]. Meanwhile, factors affect the visibility of a heavy moving vehicle included insufficient visibility issues. Low visibility caused by obstructions such as hazards may result in dangerous situations involving the driver himself as well as other road users. They may also see all or a portion of the situation but not have sufficient visual cues to be able to assess their danger of collision. In the case of underride truck crashes, they may see the large truck as moving in their lane of travel, may misjudge the truck's speed and their closing speed or distance with the truck [5].

Thus, this study evaluates the marking requirement and analyse percentages of marking requirement related to the conspicuity rear of the heavy vehicles that compliant the MS 828:2011. Increase the visibility and conspicuity it may be helpful to safety measures taken on the psychological phenomena that drivers encounter.

\subsection{REAR AND SIDE MARKING SPECIFICATION}

\subsubsection{RETROREFLECTIVE IN MALAYSIA}

The implementation of MS 828:2011 has been enforced on 1 January 2017 and all heavy vehicles with maximum gross vehicle weight (GVW) $3500 \mathrm{~kg}$ and above to be compulsory to install retroreflective rear marking in Malaysia. In July 2019 legislation made marking to MS828:2011 mandatory on new trucks and trailers with maximum gross vehicle weight (GVW) $3500 \mathrm{~kg}$ and above have to be marked with side marking and also contour marking has to be from highly reflective materials which can guarantee better visibility during night and poor weather conditions. Buses also need to be equipped with reflective rear marking [6].

Germany has presented a proposal that United Nations Economic Commission for Europe UNECE Regulation 48 should be revised, thus the installation of retro-reflective markings for a vehicle of categories $\mathrm{M}_{3}, \mathrm{~N}_{3}, \mathrm{O}_{3}$ and $\mathrm{O}_{4}$ should be compulsory [7]. UN Regulation 104 applies to retro-reflective markings for vehicles of category $M 2, M_{3}, N_{1}, N_{2}, N_{3}$, $\mathrm{O}_{1}, 02,03$ and 04.

UN Regulation 48 concerns the type-approval of vehicles that set out installation requirements for vehicle light. Meanwhile, Regulation 104 contains performance requirements for retro-reflective markings for specific categories of vehicles.

\subsection{VISIBILITY AND CONSPICUITY MARKINGS}

It could be useful to improve the visibility and conspicuity markings for safety measures taken on the psychological phenomena encountered by drivers.

Colour and Brightness: Color of the vehicle will impact brightness. The vehicle colour selected for commercial vehicles reflects as much light as possible during daytime and nighttime conditions [5]. Increasing reflectivity contributes directly to an increase in brightness. A study on emergency vehicle conspicuity by the National Bureau of Standards suggests that light-coloured vehicles are more conspicuous at night.

Photometric Specifications: The marking must follow the minimum values for the retroreflection coefficient. The retroreflection coefficient values for yellow and red should be $300 \mathrm{~cd} \cdot \mathrm{m}^{-2} . \mathrm{lx}^{-1}$ and $120 \mathrm{~cd} \cdot \mathrm{m}^{-2}$. lx-1, respectively [8], as indicated in MS 828:2011.

Size Marking: Malaysian Standard 828:2011 stated the position to install the five types of rear and side marking, as shown in Figure 1. All heavy vehicles, particularly lorries and trailers, should be fitted with rear-end markings to provide information and warnings to other drivers. The Malaysian Standard should be referred for the measurement of the plate, retroreflective, coloured regions, and the proportions of the letters for the vehicles [9]. 
Siti Aishah Yahya, Nor Azam Ramli, Syabiha Shith, and Nur Baitul Izati Rasli

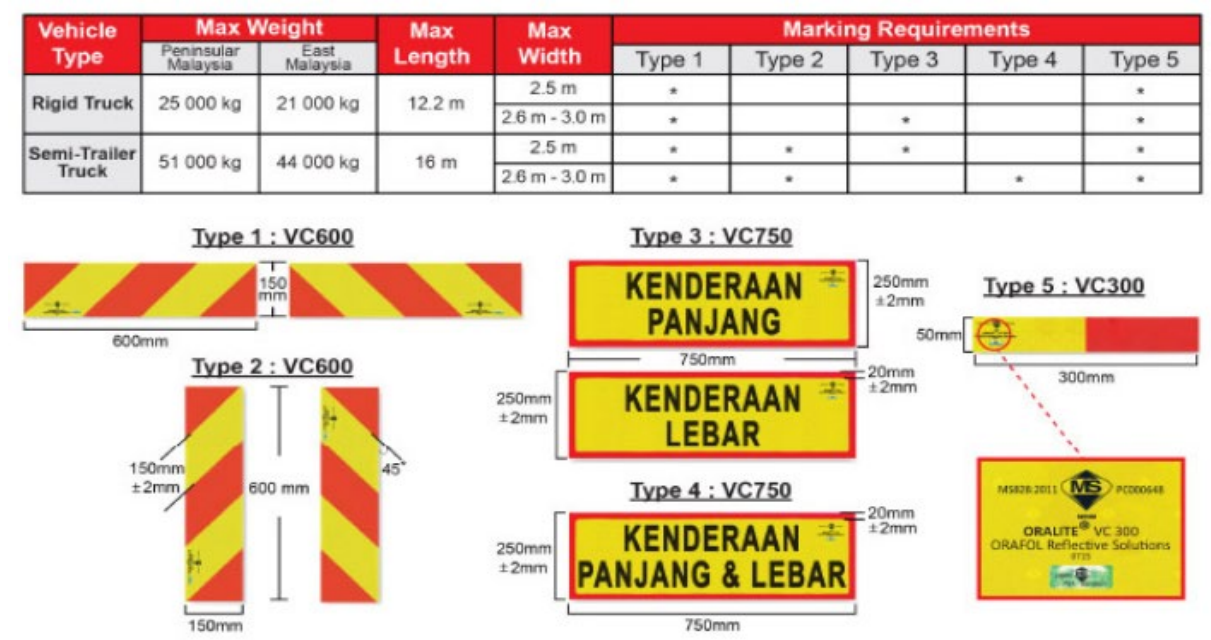

Figure 1: SIRIM Certified Commercial Vehicles Rear and Side Markings [10].

\subsection{RETRO- REFLECTIVE CHARACTERISTICS}

The retroreflective coefficient, as shown in Figure 2, can be defined as the amount of retroreflected light as the function of the viewing angle [11]. Using equations (1) and (2), the retroreflective equation coefficient can be determined.

$$
\alpha=\tan ^{-1}\left(\frac{s}{d}\right)
$$

Where:

$s=$ distance between eye and projector

$d=$ distance between viewer and screen

$\alpha=$ viewing angle

The equation indicates that the viewing angle decreases with the increasing viewer to screen distance and decreasing eye to projector distance.

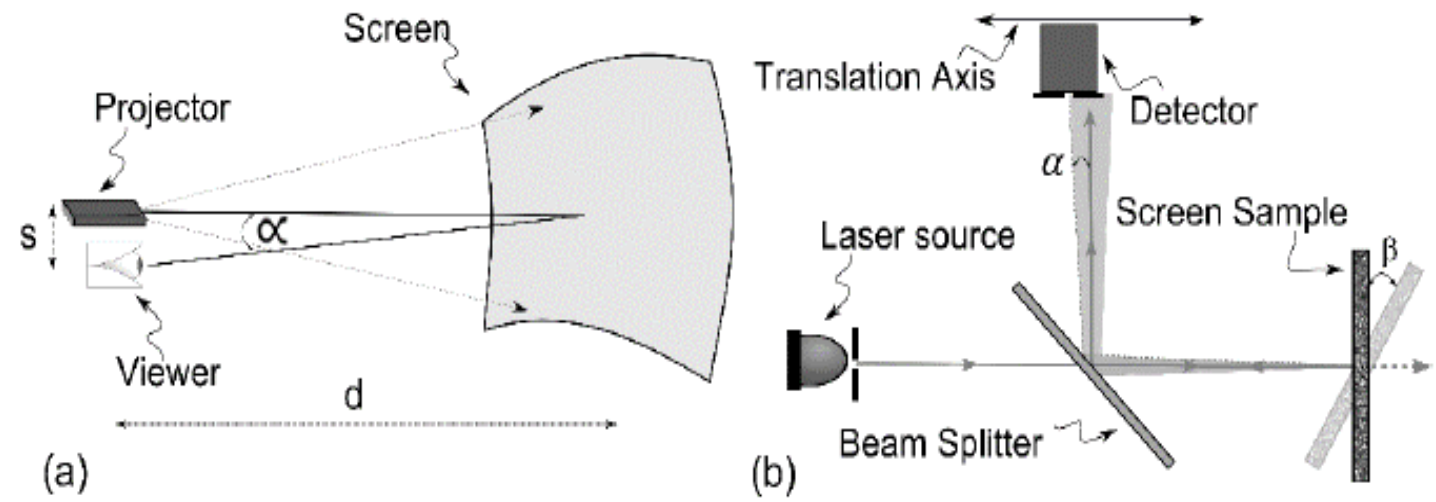

Figure 1: Retroreflective Coefficient

$$
\mathrm{R}_{\mathrm{c}(\alpha)}=\underline{\operatorname{Pd}(\alpha)}
$$

Where:

$$
0.5 \times \text { Ps }
$$

$\mathrm{R}_{\mathrm{c}(\alpha)}=$ Retro- reflective coefficient of transparent screen

$\operatorname{Pd}(\alpha)=$ Detected power at viewing angle

Ps = Power measured at sample position

International Journal of Research -GRANTHAALAYAH 
Assessment on Marking Specification of Rear Side of Heavy Goods Vehicles in Malaysia

The measured retroreflective coefficient for three different measures of the transparent screen is done for $50 \%$, $75 \%$, and $90 \%$ transparency. The amount of retroreflection decreases due to the transparency of the screen increase $[12]$.

\subsection{RETRO-REFLECTIVE MATERIALS}

Retroreflective materials contain spherical glass bead and prismatic components same as applied on highway signs and lane markings. Thousands of tiny glass beads that are bonded to the street with a higher durability binder are one of highly effective retroreflective paint. The 30-meter Observation Distance Geometry norm was chosen because it closely meets what a typical passenger car driver sees while seeing the vehicle 30 metres ahead at night [13]. Exposed-bead designs achieve higher visibility but are more easily affected by abrasion, and eventually lose reflectivity when wet [14].

Materials based on prisms also affect the efficiency of the material. There are three mutually perpendicular surfaces within the corner of a square, which transmit light in the direction of incidence. Cube corner reflectors are usually brighter than glass bead materials at small angles between the cube axis and the observation direction. However, as the angle increases, they display a sharper relative reduction in brightness [14].

\subsection{FLUORESCENT MATERIALS}

Study on fluorescent colour brightness and conspicuity acknowledge that these colours are easier to see than non-fluorescent colours [1], [2], [3], [4], [5]. Besides, fluorescent materials are observed at greater distances and with a more detailed colour perception than non-fluorescent materials. They often assist drivers to quickly recognise and respond to new road conditions, which can help minimise accidents over time. Thus, especially when considering an application to daytime truck conspicuity, is the fact that fluorescent colours were found to be more attention-getting in peripheral vision than are ordinary pigments. The disadvantage of fluorescent materials is their limited lifetime with ultraviolet exposure. The possible maximum around two years in most outdoor situations and a useful lifetime can be as short as 3 to 6 months [14].

\subsection{SELECTION OF CONSPICUITY MARKING PRODUCT}

Visibility, longevity, brightness, ease of maintenance and cleaning were the basis of the selection of conspicuous materials. Highly reflective when viewed directly from behind heavy vehicle even under the well-lit road. However, it still highly reflective in larger viewing angle during overtaking and significant even the truck itself is barely visible. 3M MS828:2011 product provides the highly visible in the daytime in the shadow and low contrast environment. The sheeting is allowed for five years when using as rear and side marking, and the face is vertical at $90^{\circ} \pm 10^{\circ}$. Clean with a sponge, cloth, soft brush using warm water and detergent. The cleaner must be wet, non- abrasive, without strong solvents and have $\mathrm{pH}$ value between 3 and 11. To remove grease, oil and tar use cloth moistened with heptane or mineral spirits. Wash with detergent and water hence, rinse thoroughly. Use high-pressure cleaning equipment based on the following criteria. The conditions should be applied at maximum pressure 80 bar, maximum temperature $60^{\circ} \mathrm{C}$, minimum of the 1-meter distance of cleaning jet from sheeting surface, cleaning wand to be held at less than $15^{\circ}$ from perpendicular to the sheeting surface and wide spray pattern [15].

\section{MATERIALS AND METHODS}

\subsection{STUDY AREA}

A site investigation was conducted to identify the rear marking availability and lighting components on the trucks and lorries in Malaysia. Lorries and trucks were observed at Jawi Toll Plaza in Nibong Tebal, Pulau Pinang, Malaysia $\left(37^{\circ} 25^{\prime} 19.1^{\prime \prime} \mathrm{N} 122^{\circ} 05^{\prime} 06^{\prime \prime} \mathrm{W}\right)$ shown in Figure 3. 


\subsection{DATA COLLECTION}

Based on the Tritech Sdn. Bhd. [10], heavy goods vehicles in Malaysia can be categorised into the rigid truck and a semi-trailer truck. About 830 lorries were observed, and data can be categorised into seven vehicle types included cargo semi-trailer, tank trailer, box truck five axles, box truck two axles, garbage truck, dumper tipper truck and cargo truck as shown in Figure 4. The rear markings effectively illuminate the outline of a vehicle at night by reflection from the headlights of vehicles following behind. In Malaysia, five types of the rear and side marking specify by Malaysian Standard (MS) 828:2011. Based on the Tritech Safety Sdn. Bhd., all truck and lorry with maximum gross vehicle weight (GVW) $3500 \mathrm{~kg}$ and above to be compulsory to install retroreflective rear marking type 1 and 5.

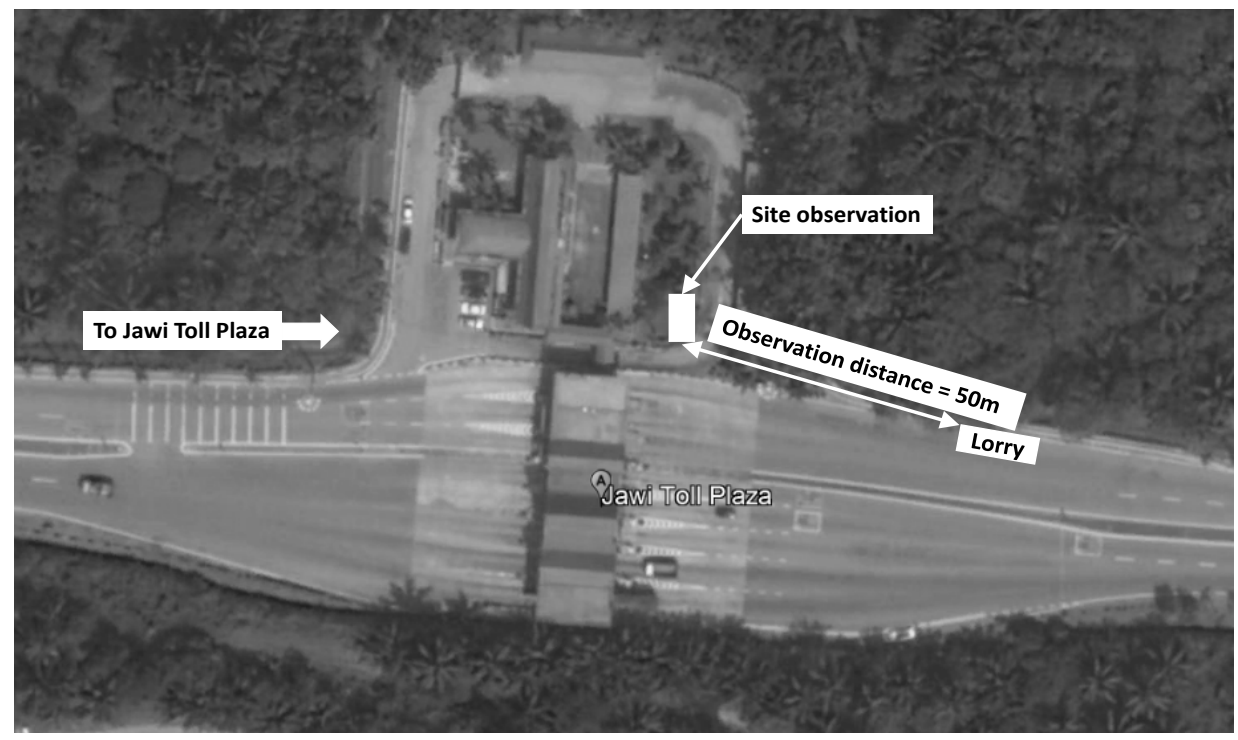

Figure 2: Jawi Toll Plaza in Nibong Tebal, Pulau Pinang

1. Cargo Semi Trailer

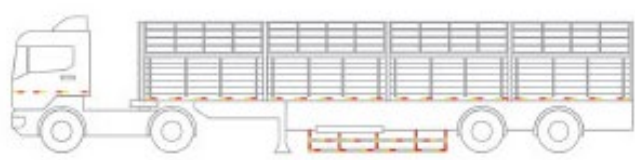

2. Petrol/ Diesel/ Oil/ Gas Tank Semi Trailer

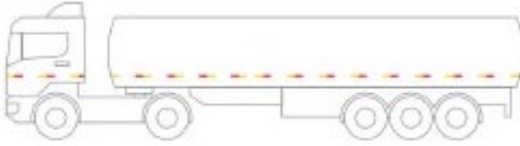

3. Box Truck 5 Axles

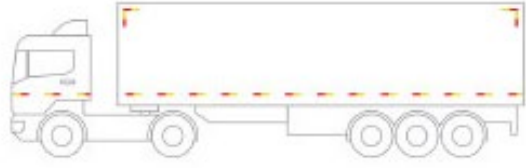

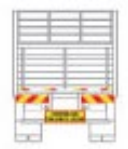
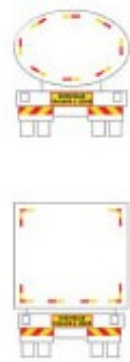

4. Box truck 2 Axles

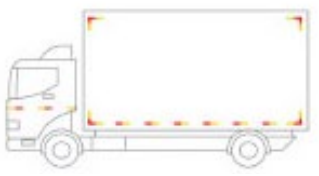

5. Garbage Truck
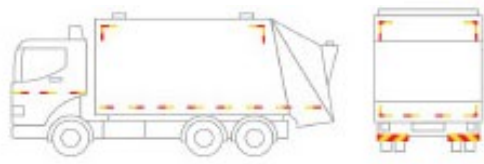

6. Dumper Tipper and Cargo Truck

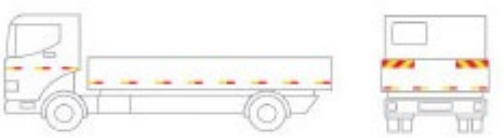

Figure 3: Types of Heavy Goods Vehicles

The video camera was used to capture several commercial trucks from 9.00 am until $5.00 \mathrm{pm}$. The proper techniques for setting up, handling and using tripods are listed below:

1) Adjust the legs so that they stand stably on the ground. Release the tensioners on the legs and raise them to the height of about 1 meter from the ground, as shown in Figure 5. Next, attach a camera to the tripod before setting the tripod, but the camera will be safer if set up the base first. It is most important to consider during extension of the legs; they are securely locked in place before mounting the camera. 


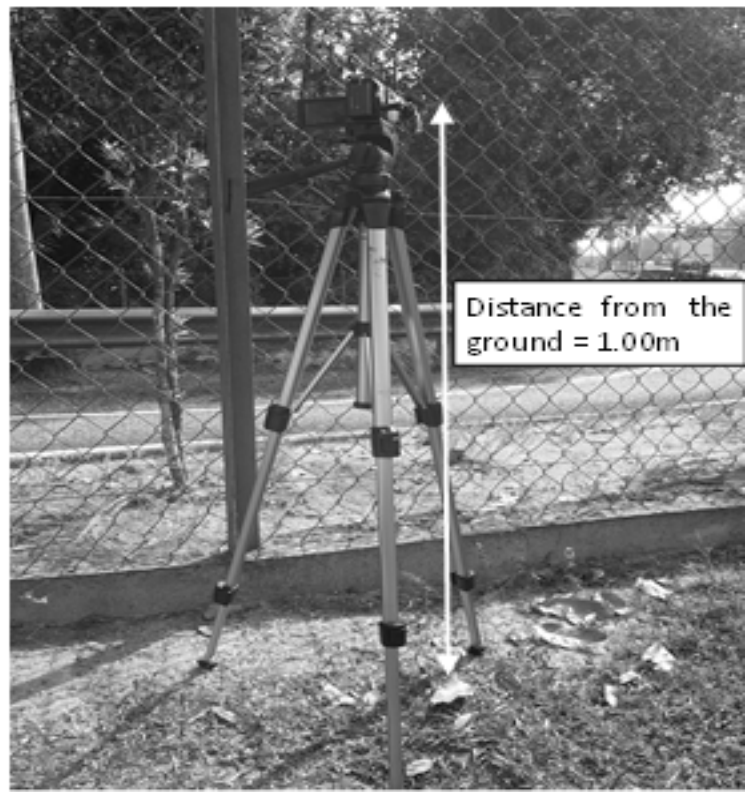

Figure 4: Height of the Tripod

2) After that, screw the camera onto the tripod. The camera might screw directly onto the tripod and might need to clamp it into place. It also needs to tighten screws to hold the camera steady. Twist the pieces together until they are snugly joined.

3) The camera on the tripod should be able to swivel for pan shots but can always move the rig to a more convenient spot. Make sure that the tripod is level and stable when you shoot. More than 830 samples of various lorries and trucks were collected randomly at Jawi Toll Plaza. The observation distance between camera and rear of the heavy vehicle about 50m, as shown in Figure 6.

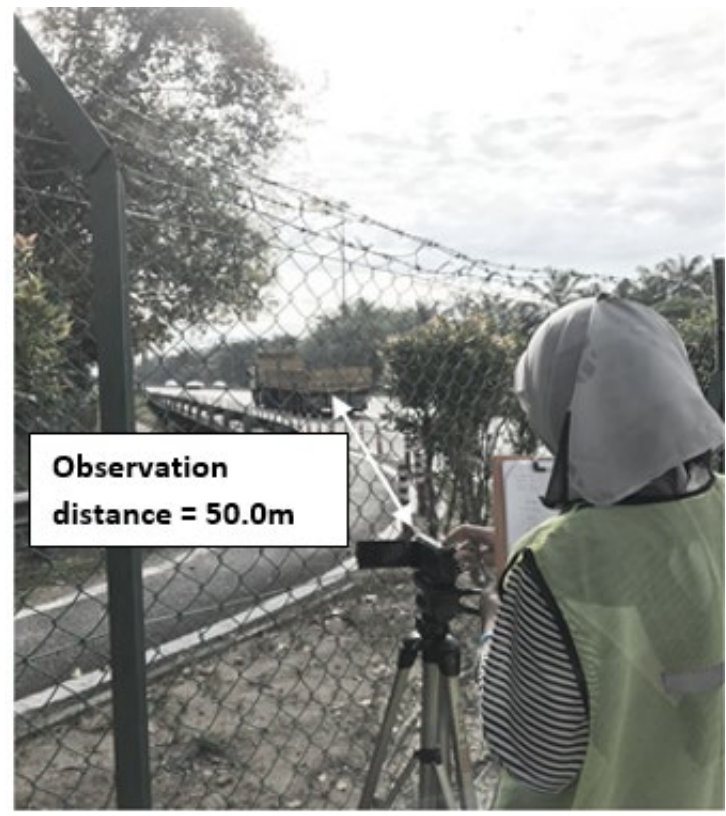

Figure 5: Observation Distance between Camera and the Truck

\subsection{DATA ANALYSIS}

Data analysis of rear-end marking on the heavy goods vehicles (HGV) using equation (3) and (4). More than 830 samples of various lorries and trucks were collected randomly at Jawi Toll Plaza. The compliance rate on the number of installations of rear-end markings which were compliant to MS 828:2011. 


\subsection{MARKING REQUIREMENT}

Percentages rear end markings $(\%)=\frac{\mathbf{N P}}{\mathbf{N}} \times 100 \%$

WHERE:

$\mathrm{NP}=$ Number of lorry passes the marking requirement

$\mathrm{N}=$ Total number of lorry

Example using equation (3) for cargo semi-trailer for marking requirement type 1:

Percentages rear end markings $(\%)=\frac{\mathbf{N P}}{\mathbf{N}} \times 100 \%$

\section{Compliances}

$$
\begin{aligned}
& =\underline{88} \times 100 \% \\
& =88 \%
\end{aligned}
$$

Percentages rear end markings $(\%)=\frac{\mathrm{NC}}{\mathrm{N}} \times 100 \%$

where:

$\mathrm{NC}=$ Number of lorry comply with the marking requirement

$\mathrm{N}=$ Total number of lorry

Example using equation (4) for cargo semi-trailer that complies with type 1 and 4:

Percentages rear end markings $(\%)=\frac{\mathrm{NC}}{\mathrm{N}} \times 100 \%$

$$
\begin{aligned}
& =\frac{75}{100} \times 100 \% \\
& =75 \%
\end{aligned}
$$

\section{RESULTS AND DISCUSSIONS}

The rear markings effectively illuminate the outline of a vehicle at night by reflection from the headlights of vehicles following behind. In Malaysia provided five types of the rear and side marking specified by Malaysian Standard (MS) 828:2011. Rear-end marking that complies with MS 828: 2011, shown in Figure 7.
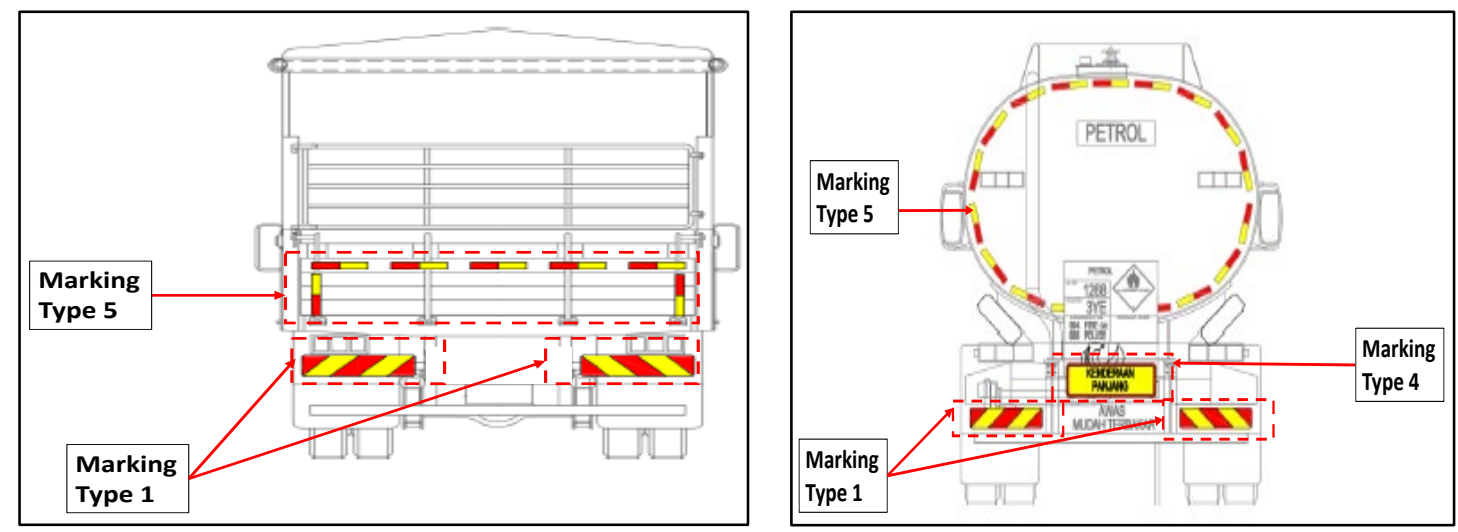

Figure 6: Retroreflective Rear Marking Type 1 and 5 


\subsection{COMPLIANCE LEVEL}

Percentages of marking requirement on the types of HGVs displayed in Table 1. Based on the Tritech Sdn. Bhd., heavy goods vehicles in Malaysia can be categorised into a rigid truck and a semi-trailer truck. Semi-trailer truck included cargo semi-trailer, tank trailer and box truck five axles. Besides that, rigid truck include; box truck two axles, garbage truck, cargo truck, and dumper truck.

\subsection{MARKING REQUIREMENT ON HEAVY GOODS VEHICLES}

From Figure 8, cargo semi-trailer, tank trailer and a box truck, five axles must be equipped with type 1, 4 and 5. Tank trailer that had the highest percentages rear end marking type 1 with $96 \%$. Cargo semi-trailer shows the lowest rates for marking requirement type 1 with $88 \%$. Meanwhile, the box truck five axles show the highest percentages rear end marking type 4 with $96 \%$. Tank trailer has the lowest percentage of marking type 4 with $78 \%$. However, only $2 \%$ tank trailer had markers type 5 installed and the remaining trailer no install markers type 5.

Figure 9 shows $75 \%$ of cargo semi-trailer equipped with rear-end marking type 1 and 4 and $25 \%$ not meet the marking requirement. The analysis also indicates that tank trailer has the lowest percentage of marking type 1 and 4 with $74 \%$. It also shows that $26 \%$ does not meet compliances. Any vehicle towing a trailer or semi-trailer could be described as articulated. Thus, tank truck can be described as an articulated truck. Berces [16] reported that from an overview of numerous vehicle accidents, it usually involves articulated trucks, rigid trucks, buses and other road users. The highest number of deaths involved in articulated trucks related accident between October 2009 to September 2010 was 120 deaths. It will possibly also play a significant role in these incidents due to visibility conditions. Improving the visibility of heavy vehicles will help to minimise the number of crashes and avoid them.

However, the box truck shows the highest rear end marking type 1 and 4 with 91\%, as shown in Figure 9. It also shows only 9\% not meet the marking requirements. As mentioned by Schmidt- Clausen [17], results of increased truck visibility demonstrated that $41 \%$ reduction of rear-end crashes and $37 \%$ decrease of side impacts could be achieved by applying reflective, outline markings on heavy vehicles. The data analysis also showed that without conspicuity markers, the probability of a collision between a truck and a car was 30 times greater.

Meanwhile, $0 \%$ of semi-trailer truck observed at the observation area no comply with rear-end marking type 1 , 4 and 5, as shown in Figure 9. This indicates that these trailer in Malaysia no have type 5 rear end marking installed. Based on Road Department Malaysia, the legislation made marking to MS828:2011 mandatory on new trucks and trailers with maximum gross vehicle weight (GVW) 3500kg and above had marked with type 5 (contour marking) in July 2019.

Table 1: Marking Requirement on the Types of Heavy Goods Vehicles

\begin{tabular}{|c|c|c|c|c|c|c|c|c|}
\hline No & Sample, & Lorry Types & \multicolumn{3}{|c|}{ Marking Requirements } & \multicolumn{3}{|c|}{ Compliance } \\
\hline \multirow[t]{2}{*}{1.} & \multirow[t]{2}{*}{100} & \multirow[t]{2}{*}{ Cargo Semi Trailer } & Type 1 & $\begin{array}{c}\text { Type } \\
4\end{array}$ & Type 5 & $\begin{array}{c}\text { Comply } \\
\text { (Type } \\
1 \& 4)\end{array}$ & $\begin{array}{c}\text { Comply } \\
\text { (Type } \\
1,4 \& 5)\end{array}$ & $\begin{array}{c}\text { Not } \\
\text { comply }\end{array}$ \\
\hline & & & 88 & 86 & 0 & 75 & 0 & 25 \\
\hline \multicolumn{3}{|c|}{ Percentage (\%) } & $88 \%$ & $86 \%$ & $0 \%$ & $75 \%$ & $0 \%$ & $25 \%$ \\
\hline \multirow[t]{2}{*}{2.} & \multirow[t]{2}{*}{50} & \multirow[t]{2}{*}{$\begin{array}{c}\text { Petrol/ Diesel/ Gas Tank } \\
\text { Trailer }\end{array}$} & Type 1 & $\begin{array}{c}\text { Type } \\
4\end{array}$ & Type 5 & $\begin{array}{c}\text { Comply } \\
\text { (Type 1\& } \\
4 \text { ) }\end{array}$ & $\begin{array}{c}\text { Comply } \\
\text { (Type } \\
1,4 \& 5)\end{array}$ & $\begin{array}{c}\text { Not } \\
\text { comply }\end{array}$ \\
\hline & & & 48 & 39 & 1 & 37 & 0 & 13 \\
\hline \multicolumn{3}{|c|}{ Percentage (\%) } & $96 \%$ & $78 \%$ & $2 \%$ & $74 \%$ & $0 \%$ & $26 \%$ \\
\hline \multirow[t]{2}{*}{3.} & \multirow[t]{2}{*}{100} & \multirow[t]{2}{*}{ Box Truck 5 Axles } & Type 1 & $\begin{array}{c}\text { Type } \\
4\end{array}$ & Type 5 & $\begin{array}{c}\text { Comply } \\
\text { (Type } 1 \& \\
4)\end{array}$ & $\begin{array}{c}\text { Comply } \\
\text { (Type } \\
1,4 \& 5)\end{array}$ & $\begin{array}{c}\text { Not } \\
\text { comply }\end{array}$ \\
\hline & & & 95 & 96 & 0 & 91 & 0 & 9 \\
\hline \multicolumn{3}{|c|}{ Percentage (\%) } & $95 \%$ & $96 \%$ & $0 \%$ & $91 \%$ & $0 \%$ & $9 \%$ \\
\hline
\end{tabular}


Siti Aishah Yahya, Nor Azam Ramli, Syabiha Shith, and Nur Baitul Izati Rasli

\begin{tabular}{|c|c|c|c|c|c|c|c|}
\hline \multirow[t]{2}{*}{4.} & \multirow[t]{2}{*}{250} & \multirow[t]{2}{*}{ Box Truck 2 Axles } & Type 1 & Type 5 & $\begin{array}{l}\text { Comply } \\
\text { (Type 1) }\end{array}$ & $\begin{array}{c}\text { Comply } \\
\text { (Type } 1 \\
\& 5)\end{array}$ & $\begin{array}{c}\text { Not } \\
\text { comply }\end{array}$ \\
\hline & & & 240 & 0 & 240 & 0 & 10 \\
\hline \multicolumn{3}{|c|}{ Percentage (\%) } & $96 \%$ & $0 \%$ & $96 \%$ & $0 \%$ & $4 \%$ \\
\hline \multirow[t]{2}{*}{5.} & \multirow[t]{2}{*}{30} & \multirow[t]{2}{*}{ Garbage Truck } & Type 1 & Type 5 & $\begin{array}{l}\text { Comply } \\
\text { (Type 1) }\end{array}$ & $\begin{array}{l}\text { Comply } \\
\text { (Type } 1 \\
\& 5)\end{array}$ & $\begin{array}{c}\text { Not } \\
\text { comply }\end{array}$ \\
\hline & & & 5 & 0 & 5 & 0 & 25 \\
\hline \multicolumn{3}{|c|}{ Percentage (\%) } & $17 \%$ & $0 \%$ & $17 \%$ & $0 \%$ & $83 \%$ \\
\hline \multirow[t]{2}{*}{6.} & \multirow[t]{2}{*}{250} & \multirow[t]{2}{*}{ Cargo Truck } & Type 1 & Type 5 & $\begin{array}{l}\text { Comply } \\
\text { (Type 1) }\end{array}$ & $\begin{array}{l}\text { Comply } \\
\text { (Type } 1 \\
\& 5 \text { ) }\end{array}$ & $\begin{array}{c}\text { Not } \\
\text { comply }\end{array}$ \\
\hline & & & 223 & 0 & 223 & 0 & 27 \\
\hline \multicolumn{3}{|c|}{ Percentage (\%) } & $89 \%$ & $0 \%$ & $89 \%$ & $0 \%$ & $11 \%$ \\
\hline \multirow[t]{2}{*}{7.} & 50 & Dumper Tipper Truck & Type 1 & Type 5 & $\begin{array}{c}\text { Comply } \\
\text { (Type 1) }\end{array}$ & $\begin{array}{l}\text { Comply } \\
\text { (Type } 1 \\
\& 5 \text { ) }\end{array}$ & $\begin{array}{c}\text { Not } \\
\text { comply }\end{array}$ \\
\hline & & & 42 & 0 & 42 & 0 & 8 \\
\hline \multicolumn{3}{|c|}{ Percentage (\%) } & $84 \%$ & $0 \%$ & $84 \%$ & $0 \%$ & $16 \%$ \\
\hline
\end{tabular}

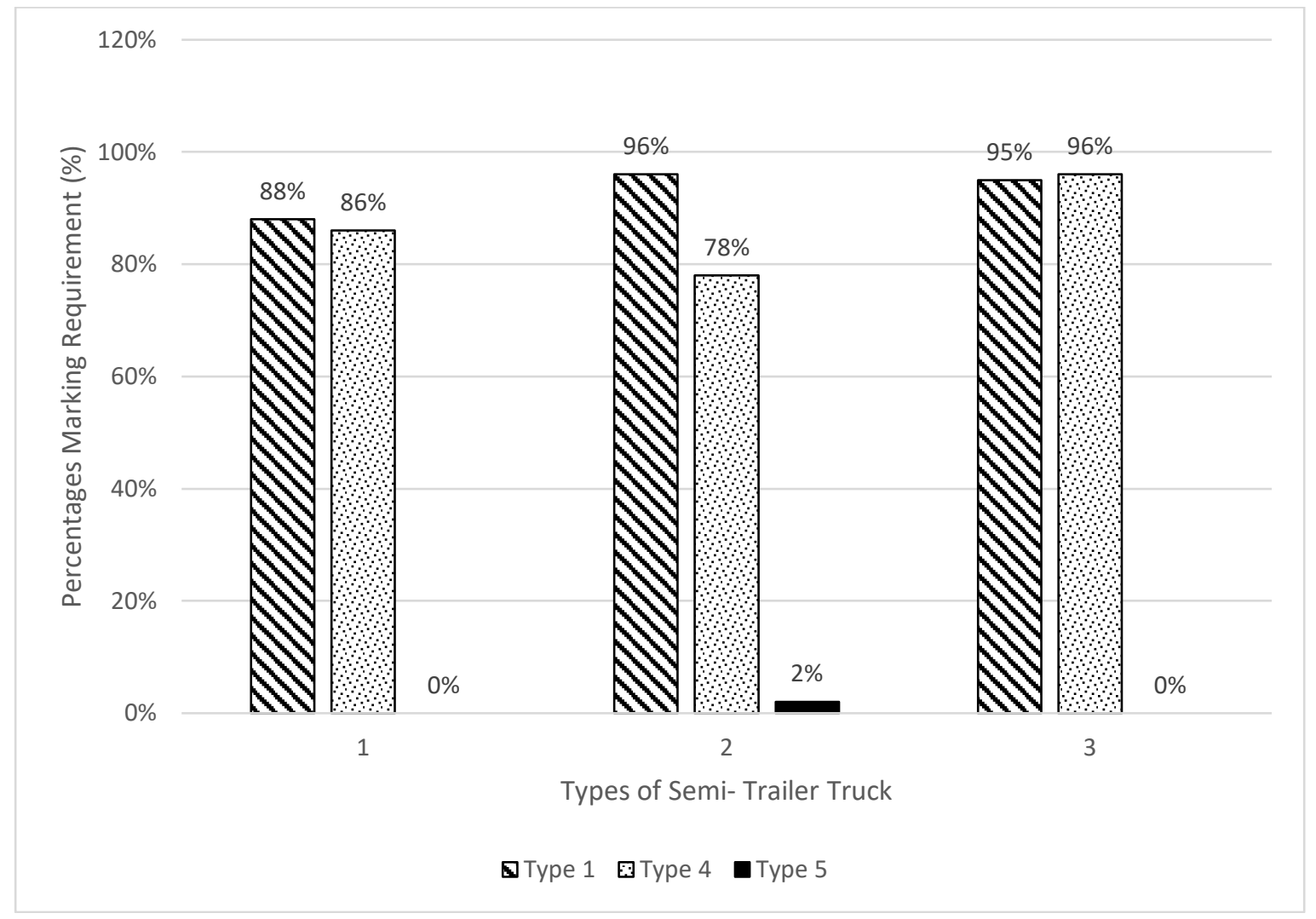

Figure 7: Percentages Marking Requirement on Semi-trailer Truck 


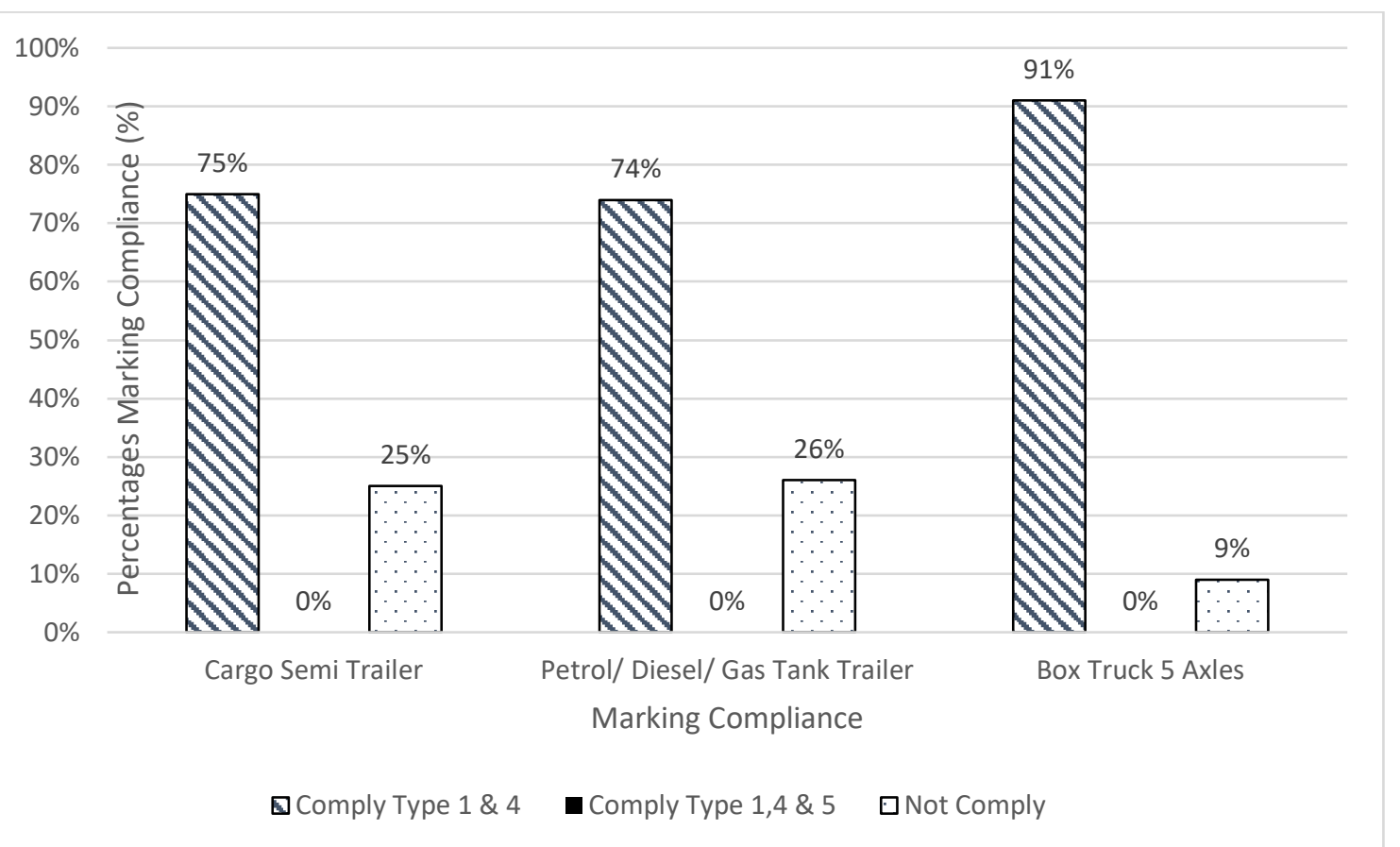

Figure 8: Percentages Marking Compliance on Semi-trailer Truck

Rigid truck included box truck two axles, garbage truck, cargo truck, and dumper tipper truck should be equipped with type 1 and type 5 markers. From Figure 10, box truck two axles represent the highest percentages rear end marking types 1 with 96\%. Meanwhile, the garbage truck had rear end marking type 1 with $17 \%$ and the remaining $83 \%$ of installed markers type 1 was found to be either in bad condition or had segments missing. Rear marking type 5 had a significant role in the accidents by improving heavy vehicle visibility that helps to reduce and prevent the number of collisions. The relative performances of ECE 104 and ECE 70. were examined by Cook [18]. Results showed that the most noticeable contour markings as presented in ECE 104 are. Also, full-contour markings are the most effective in contrast with line-markings. However, $0 \%$ of rigid truck observed at the observation area not equipped with marking type 5, as shown in Figure 10.

According to the analysis in Figure 11, percentage marking compliance of the truck, box truck two axles represents highest percentages marking compliance type 1 with $96 \%$ and the remaining only $4 \%$ not meet marking requirement. Furthermore, cargo and dumper truck show percentages marking that not comply with $11 \%$ and $16 \%$ respectively. This show cargo and dumper truck are marked with the poor design such that the marking obscured by any goods or canvas cover at any time and reduce visibility to other road users. The garbage truck contributes higher percentages among others truck about $83 \%$ not meet the requirement. The higher percentage of this type of compliance involving garbage truck due to the rear marking not maintained in a clean, bad condition and not install marking requirement while using the road.

Dirt on the tape significantly decreased its rear-impact efficacy. As reported by Lawton [19], various circumstances such as different lighting conditions, weather conditions, soil and characteristics of the observer have been investigated in some research in which retroreflective tape maybe most or least effective and therefore most useful in its use. Studies on the retroreflective output of tape under varying degrees of soil, according to SchmidtClausen [17]. For example, markings near the lower part of the vehicle nearest to the road are more vulnerable to dirt build-up and are therefore likely to be less effective. Amirudin et al. [20] studied this problem at Sungai Buloh Rest Area for 100 samples from both lorries and trucks. The results show that condition of retroreflective on the rigid lorry was $20 \%$ in good condition, $66 \%$ was covered by dirt and $14 \%$ having missing segment compared to the articulated lorry with good, covered with dirt and the missing segment of $16 \%, 58 \%$ and $26 \%$, respectively. 
Siti Aishah Yahya, Nor Azam Ramli, Syabiha Shith, and Nur Baitul Izati Rasli

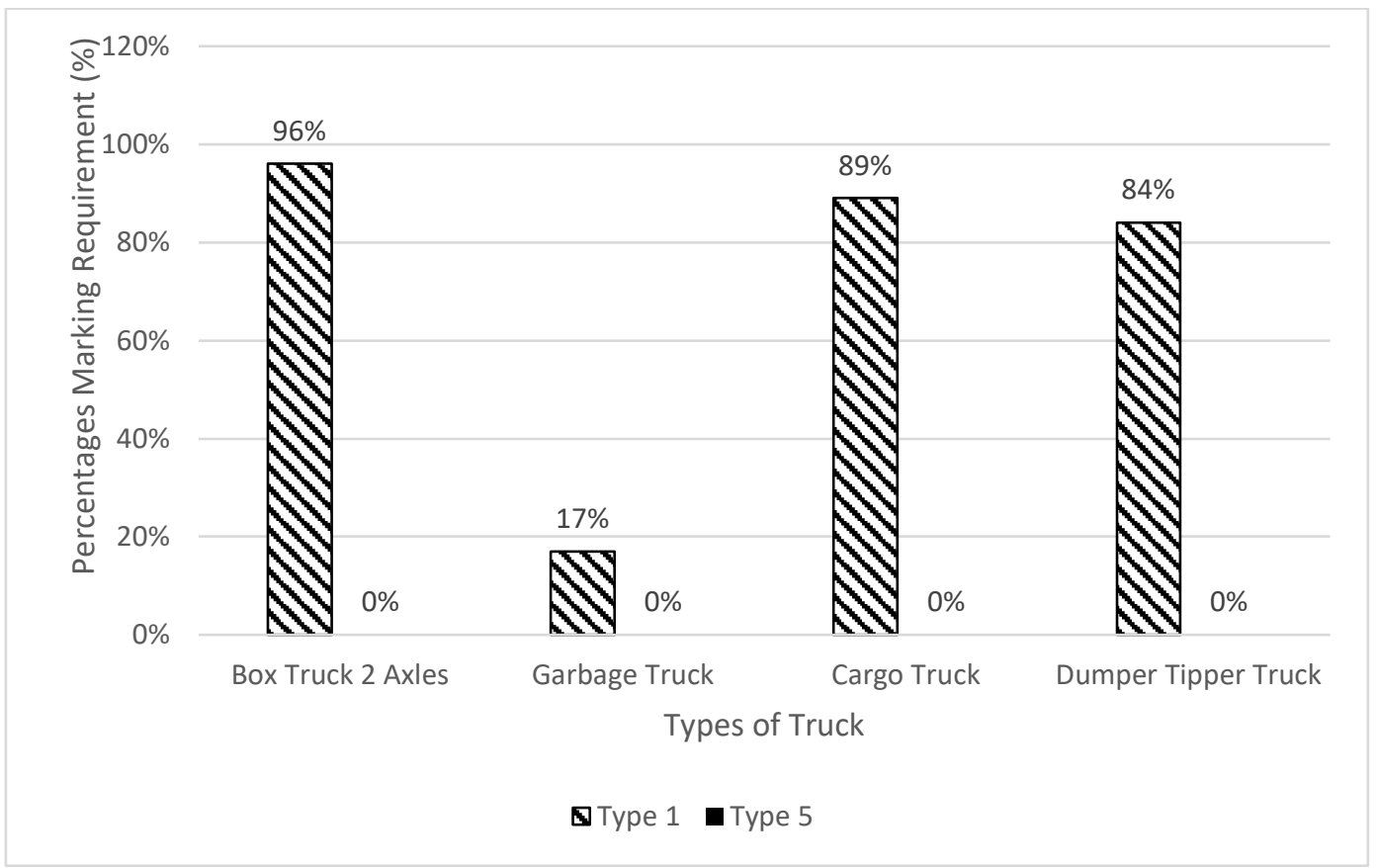

Figure 9: Percentages Marking Requirement on Truck

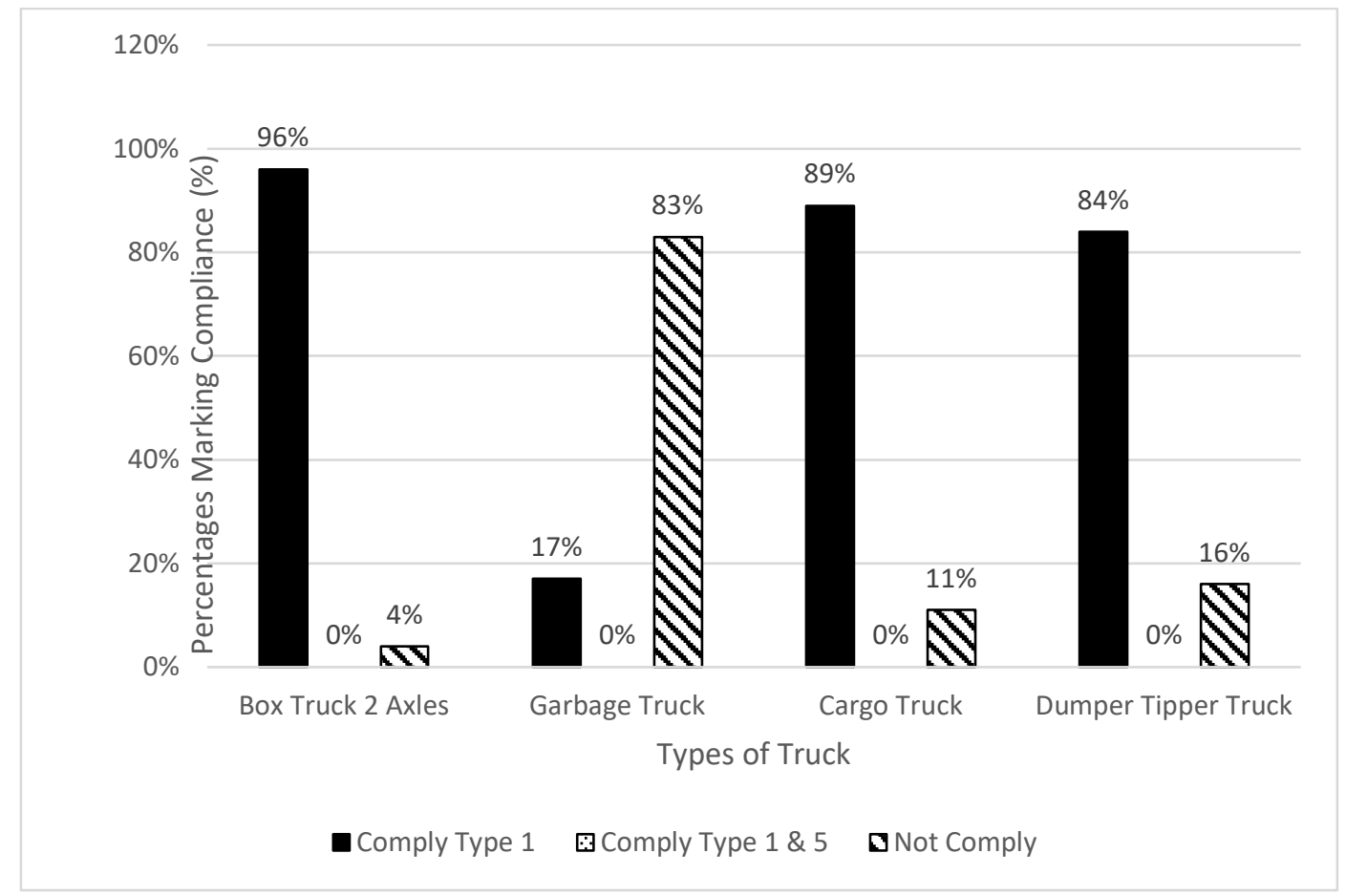

Figure 10: Percentages Marking Compliance on Truck

\section{CONCLUSIONS AND RECOMMENDATIONS}

Based on the findings from this study, it is found that the highest compliance level of marking requirement was $96 \%$ which is box truck two axles. Meanwhile, other categories were between 17\% to 91\%. Rear-end marking type 5 was not being installed by any HGVs, although all trucks and trailers with maximum gross vehicle weight (GVW) $3500 \mathrm{~kg}$ and above were compulsory to be marked with type 5 (contour marking) starting on 1 July 2019. This shows observations were conducted on the number of installations of rear markings should make some improvement to 
Assessment on Marking Specification of Rear Side of Heavy Goods Vehicles in Malaysia

reduce the severity and the number of road accidents, especially rear-end and under ride collisions by recommended a safe following distance.

\section{SOURCES OF FUNDING}

This research received no specific grant from any funding agency in the public, commercial, or not-for-profit sectors.

\section{CONFLICT OF INTEREST}

The author have declared that no competing interests exist.

\section{ACKNOWLEDGMENT}

Thanks to Environmental Assessment and Clean Air Research (ECAR) and RTD, Pulau Pinang.

\section{REFERENCES}

[1] Lan, T.T., Kanitpong, K., Tomiyama, K., Kawamura, A. and Nakatsuji, T., (2019). Effectiveness of retro-reflective tape at the rear of heavy trucks to increase visibility and reduce rear-end collisions. IATSS Research, 43(3),176-184.

[2] Sullivan, J.M. and Flannagan, M.J., (2012). Heavy trucks, conspicuity treatment, and the decline of collision risk in darkness. Journal of safety research, 43(3), pp.157-161.

[3] International Transport Forum (2013), Annual Report 2013.

[4] Ministry of Transport Malaysia (2017), Transport Statistics Malaysia, ISSN: 0128-2778, Ministry of Transport, Malaysia.

[5] Roberts, G. L. and Lynn, C. (2003), Passenger Vehicle Crashes Into Stationary Large Trucks: Incidence and Possible Countermeasures, Virginia Transportation Research Council, No. VTCR 03-CR17, pp. 62.

[6] Ibrahim, M. F. (2019), Slide Presentation Pelaksanaan Pemasangan Reflektor MS828:2011 bagi Kenderaan yang Membawa Barangan Berbahaya at The JPJ Seberang Jaya, Pulau Pinang on 23 January 2019.

[7] United Nations (2014), Addendum 47: Regulation No. 48 Uniform provisions concerning the approval of vehicles with regard to the installation of lighting and light-signalling devices.

[8] Malaysian Standard (2016), Road vehicles - Rear and side marking - Specification (Second revision), MS 828: 2011, Department of Standards Malaysia.

[9] Mohamad Radzi, M. A., Zainal Abidin, A. N. S., Rahman, M. K., Solah, M. S., Hamzah, A., Norlen, M. and Voon, W. S. (2016), Rear-end Markers ( REMs ) Issues involving Trucks and Lorries in Malaysia, Research Report, Malaysian Institute of Road Safety Research (MIROS) Malaysia, ISBN 978-967-5967-75-7.

[10] Tritech (2015), MS828:2011 SIRIM Certified Commercial Vehicles Rear and Side Marking - Light Reflectors. Available from:< http://www.tritech.com.my/main/list/ms8282011-sirim-certified-commercial-vehiclesrear-amp-side-markings---light-reflectors-253>. [19 March 2019].

[11] Morgan, C. (2001). The effectiveness of retroreflective tape on heavy trailers (No. HS-809 222).

[12] Soomro, S.R. and Urey, H. (2016), Design, Fabrication and Characterization of Transparent Retro- Reflective Screen, Optics Express, Vol. 24, No. 21, pp.24232-24241.

[13] Hatzi, P. (2019), Retroreflectivity, Highway Traffic Safety Administration, US Department of Transportation. Available from: <https://library.unt.edu/gpo/OTA/featproj/fp_te29.html>. [28 February 2019].

[14] Burger, W. J. and Smith, R. L. (1987), Use of Reflectorization to Reduce Truck- Trailer Accidents, Transportation Research Record, No. 1149, pp. 50- 55.

[15] Mahi Din. M. S. (2019), Slide Presentation 3M MS828:2011 Conspicuity Marking Solution at The JPJ Seberang Jaya, Pulau Pinang on 23 January 2019.

[16] Berces, A., 2011, November. Improving road safety by increased truck visibility. In Proceedings of the Australasian road safety research, policing and education conference (Vol. 15). Monash University.

[17] Schmidt-Clausen, H.J. ed., 2001. Proceedings of the Symposium. Herbert Utz Verlag. 
[18] Cook, S., Quigley, C. and Clift, L., 1999. Motor vehicle conspicuity: an assessment of the contribution of retroreflective and fluorescent materials. DfT Report.

[19] Lawton, C., Richardson, J. and Welsh, R., 2005. Assessment of the safety benefit of retro-reflective markings on HGVs and buses. Report for Department for Transport USA.

[20] Amirudin, M.M., Syukri, Z.A.N. and Kak, D., (2017). Assessing retro-reflective markers (RRMs) usage on heavy vehicles with respect to MS 828: 2011. In MATEC Web of Conferences (Vol. 90, p. 01033). EDP Sciences. 